\title{
Management Consulting, Global Markets and Corporate Networking
}

\author{
Silvio M. Brondoni*
}

\begin{abstract}
Within economic globalization, management consulting has become an important source for innovation in management, forming a bridge between academia, firms, and thought leaders in other fields.

In the 1980s and 1990s, management consulting has grown quickly in US and in Europe. The current trend in the market is a clear differentiation of management consulting firms.

Currently, there are four main types of consulting firms. First, the large management and strategic consulting specialists that offer only strategy consulting and are specialized in some specific industry. Second, the boutique firms, often quite small, focusing on areas of consulting expertise in specific industries or technologies. Third, the medium-sized information technology consultancy networks, that mix boutique style with some of the typical services and technologies global players offer their clients. Finally, the large networks. Diversified organizations that offer a wide range of services.
\end{abstract}

Keywords: Management Consulting; Corporate Networking; Global Markets; Management Consulting Firms; Consultancy Network

\section{Economic Globalization \& Management Consulting}

Within economic globalization, management consulting has become an important source for innovation in management, forming a bridge between academia, firms, and thought leaders in other fields. As a result, management consulting firms can use a variety of tools and techniques to approach business problems. Management consulting industry comprises now strategy consulting and operations consulting and refers to the practice of helping companies to improve performance through analysis of existing business problems and development of future plans. Management consulting may involve the identification and cross-fertilization of best practices, change management and coaching skills, strategy development or operational improvement, technology implementations, analytical techniques.

*Full Professor of Marketing, University of Milan-Bicocca (silvio.brondoni@ unimib.it)

Edited by: ISTEI - University of Milan-Bicocca

ISSN: 1593-0319

Brondoni Silvio M., Management Consulting, Global Markets and Corporate Networking, Symphonya. Emerging Issues in Management (symphonya.unimib.it), n. 1, 2007, pp. 16-25

http://dx.doi.org/10.4468/2007.1.03brondoni 
Management consultants can also rely on their outsider's perspective to provide fair recommendations. As more 21st-century global companies come to specialize in core activities and outsource the rest (network organization), they have greater need for external specialists who can interact with other companies, their comakers, their customers, and their suppliers. Companies that get it right will build complex talent-based competitive advantages that competitors won't be able to imitate easily and in short times. Thus the traditional organization, where a few top managers coordinate the pyramid below them, is being upset.

Management consultants generally bring formal frameworks or methodologies to identify problems or suggest more effective or efficient ways of performing business tasks. Management consulting refers to providing business consulting services, but often it can be difficult to distinguish between management consulting and other consulting practices such as Information Technology consulting, because these fields directly support business operations and often overlap the field of management consulting.

\section{Management Consulting Beginning in USA and in Europe}

The main reason why management consulting industry grew first in the USA is because of deep cultural factors. Contrary to Europe, US management and Boards people alike might not be competent in all circumstances; therefore, buying external competency and services was seen as a positive way to solve a business problem. Indeed, management consulting defines a business relation to management.

By contrast, in Europe, management is compelled to be competent at all times and for all economic, emotional and social dimensions. This is referred to as the euro pan 'pater familias' business-pattern. Therefore seeking and paying for external advice was seen as inappropriate for a long time and just at the beginning of globalization (1980s). Conversely it must also be said that in those days (and still today) the average level of education of the executives was significantly lower in the USA than in Europe, where managers were 'Grandes Ecoles' graduates (France) or 'Doktor' (Germany). The combination of these two factors made it difficult for consulting to emerge in Europe. It was only after World War II, in the wake of the development of the international trade led by the USA, that management consulting emerged in Europe.

\section{The Glamorous History of Management Consulting Industry}

Management consulting industry grew with the development of management. Arthur D. Little, the famous MIT professor, founded in 1886 the first management consulting firm on the same name. Arthur D. Little originally specialized in technical research and just later became a general management consultancy. Edwin G. Booz, a graduate of the Kellogg School of Management at Northwestern University, founded in 1914 Booz Allen Hamilton as a management consultancy and the first to serve both industry and government. The first pure management and 
strategy consulting company was McKinsey \& Company. McKinsey was founded in Chicago during 1926 by James O. McKinsey, a professor at the University of Chicago Graduate School of Business, but the modern McKinsey was shaped by Marvin Bower, who believed that management consultancies should adhere to the same high professional standards as lawyers and doctors. McKinsey is credited with being the first to hire newly MBAs graduated from top schools to staff its projects. Andrew T. Kearney, an original McKinsey partner broke off and started A.T. Kearney in 1937, PA-Personnel Administration was founded in 1943 -during Britain's war effort- by three Englishmen: Ernest E. Butten, Tom H. Kirkham and Dr. David Seymour.

After World War II, a number of new management consulting firms formed, most notably Boston Consulting Group, founded in 1963, which brought a rigorous analytical approach to the study of management and strategy.

Booz Allen, McKinsey, BCG, and Harvard Business School, during the 1960s and 70s, developed the tools and approaches that would define the new field of strategic management, setting the groundwork for future consulting firms. Another major player of more recent fame is Bain \& Company, whose focus on shareholder wealth (including its successful private equity business) set it apart from older companies. Also significant was the development of consulting arms by both accounting firms (such as Accenture of the now defunct Arthur Andersen) and global IT services companies (such as IBM Global Services, which acquired PwC Consulting). Though not focused on strategy problem solving, these consulting companies often were well-managed and arrived on client sites in force.

\section{Global Competition and Management Consulting Firms}

In the 1980s and 1990s, management consulting has grown quickly in US and in Europe. The current trend in the market is a clear differentiation of management consulting firms. McKinsey, Bain, and BCG retain their strong strategy focus, while many other generalist management consultancies such as Accenture and Capgemini are broadening their offering increasing into high volume, lower margin work such as system integration. Today, for instance, McKinsey \& Co offers worldwide management consulting services in selected industries, all with a global competitive edge, (Automotive; Energy, Resources, Materials; Financial Services; Food \& Agriculture; Health Care; High Tech; Media \& Entertainment; Non-profit; Public Sector; Retail \& Consumer Goods; Telecommunications; Transportation), and for many corporate function, as: Corporate Finance; Economic Studies; Governance; Information Technology; Marketing; Operations; Organization; Strategy.

Currently, there are four main types of consulting firms. First, the large management and strategic consulting specialists that offer only strategy consulting and are specialized in some specific industry (such as Arthur D. Little, A.T. Kearney, Bain \& Company, Boston Consulting Group, Booz Allen Hamilton, and McKinsey \& Company).

Second, the boutique firms, often quite small, focusing on areas of consulting expertise in specific industries or technologies. For instance, Roland Berger is well- 
known in Europe for its skills in downsizing and cost-killing, while Monitor Group is focused on the pharmacy industry and assistance to developing countries' governments. Most of the boutiques were founded by academicians or famous business theorists.

Third, the medium-sized information technology consultancy networks (such as Hitachi Consulting) that mix boutique style with some of the typical services and technologies global players offer their clients.

Finally, the large networks. Diversified organizations (such as Accenture, BearingPoint, Capgemini, Deloitte and IBM Global Services) that offer a wide range of services, including information technology consulting. linformation technology consulting (IT) has been one of the fastest-growing segments of business. This segment includes consultants focused on e-commerce; telecommunications; intranet and Internet strategies and functionality; hardware systems design and implementation; software design, acquisition and implementation; and web site design and operation. During the tech boom of the 90s, global corporations everywhere wanted to quickly ramp up new systems, from web sites to private data networks to advanced e-commerce systems. They turned to consultants, and the IT consulting companies boomed. During the $90 \mathrm{~s}$, IT consultancies, through a wide commercialization of the Internet and fibber optics, as well as the rapid spread of networked computing, created partnerships with leading hardware and software manufacturers so that they could easily recommend, sale and install technology system packages.

Today's largest IT consulting firms often provide outsourced IT services of many types. In fact, successful consultancies with IT roots have evolved into full-service companies. In many cases, they are integral departments within larger technologybased companies.

The IBM Global Services unit of computer giant IBM best illustrates this trend. At such tech firms, a large portion of income is derived from outsourcing. That is, once these IT services firms have determined a client's needs during a consulting or analysis phase, they may deliver key-services that include day-to-day operation of the client's computer department and/or other departments. HP has also been focusing on its large consulting and services unit. Likewise, many companies outside of the computer hardware and software field have successfully blended consulting and outsourcing into their offerings, developing dependable additional revenue sources by offering a complete line of services to their clients.

$\square$ The biggest development in IT consulting today is the extremely rapid growth of major companies that are based in India but compete globally, such as Tata Consultancy Services (TCS). Tata has quickly become a $\$ 4$ billion annual revenues firm and a major contender in the global IT sector. Additional global leaders headquartered in India include Wipro and Infosys. Additional very hot competition for IT consulting budgets comes from software companies, such as Oracle, that have quickly built up large consulting units of their own. Even Dell, once a firm focused on the efficient manufacture and direct sales of PCs 
and servers now offers a complete system design and installation service.

Original Equipment Manufacturers (OEMs) of a wide range of products and components, (from laptop computers to hard drives to automobile components) now consult intensely with their clients in the product development phase, and are later involved in the actual manufacturing. Many OEMs led so into Original Design Manufacturers (ODMs) that consult with, design for and then manufacture for their clients. For example, an ODM might determine the needs for an in-dash stereo/radio system of an automaker client, design the system and finally manufacture the system. The automobile industry has become an environment in which major manufacturers, such as GM, rely heavily on a handful of component and systems manufacturers, to consult in the design and engineering phase of new car planning.

Contract electronics manufacturers such as Flextronics consult heavily with their clients in the design of new products, whether they are computers, stereos or telecommunications equipment.

As technology has advanced rapidly and microchips have become integral components of many everyday items, consulting regarding design and implementation has become necessary to many types of manufacturers. Likewise, many types of service providers, such as those in telecommunications, must consult to a large extent with end customers regarding their systems' needs. Consulting in these types of situations may or may not result in additional fees, but in many cases the consulting functions at manufacturing and services firms have been developed into true profit centers with specific fee structures.

\section{Global Markets and Management Consulting Industry}

The economic globalization introduced many changes, but the consulting business remains one of the most prestigious and secretive sectors in the world of business.

In recent years the economic globalization developed the consulting industry in most of the developed world. Moreover changing demands from great corporations and governments led major international consulting firms to become very global in nature, but unfortunately with tighter budgets, more competitive bidding and shorter engagements in many cases. In particular, management consulting, IT consulting and human resources consulting have become extremely competitive.

Recently, in the US market major consulting firms are enjoying revenue gains and once again are hiring top college grads as well as experienced consultants and analysts. Corporate clients are also more open to consultants specializing in security matters and global politics. Meanwhile, government clients are engaging consulting organizations for advice in home security and anti-terrorist tactics.

Also outside the US, the globalization pushed up management consulting firms. To a growing degree, however, off shoring of such tasks is becoming necessary in order to conduct management consulting projects in the nations where management 
practices must be applied. As multinational companies headquartered in the US and elsewhere continue to open offices, factories and research facilities in other nations, consultants must follow in order to best practice their skills.

$\square$ There are deep needs of high-level consultants in China, and they are in very high demand in India as well. Global business growth from Europe throughout North America to Asia/Pacific is fuelling demand for consulting of all kinds, including management consulting, HR consulting, industrial consulting and technology consulting. Meanwhile, many types of consulting and accounting projects are being off shored, due to efforts by firms in North America and Europe that wanted to take advantage of lower hourly fees.

The global management consulting industry refers today to organizations primarily engaged in providing advice and assistance on business and management corporate issues, such as: strategic planning (strategic management consulting; global, international and local business consulting; change management consulting; health care consulting); organizational planning (business plans; growth strategies and global change); consulting outsourcing (transportation, logistics and supply chain management, E-commerce); financial planning and budgeting; marketing positioning and sales policies (sales management training; customer service training and customer loyalty and retention training); human resource policies, practices, and planning (leadership development, management and team development, management and employee training, executive coaching); production scheduling (project management; value analysis); Information \& Communication Technology planning and implementation of methods; control planning; dispute resolution; consulting to governments, homeland security and defence.

In particular, today's environment of high-level, global corporate mergers and acquisitions is helping to drive demand for consulting, as consulting firms large and small find themselves assisting hedge funds, asset managers and corporate acquisitions specialists.

$\square$ India and China are investing heavily in their own upper-level education systems with the aim to turn out world-class MBAs. Many Asian nations have already achieved excellent success in this regard, including Korea, Singapore, Taiwan and Japan.

The consulting industry is a multifaceted, global business sector that is facing many challenges and evolving quickly. At the highest level of the business is 'management consulting', the segment that advises top executives and boards of directors of largest global firms on strategy and organization. These consultants' engagements for a multinational corporation may include analysis of multiple divisions and involve travel to several continents. Management consultants may take assignments involving many aspects of a client's business, including marketing, acquisitions, finance, information technology, organizational changes, human resources, disinvestments, government relations, facilities, telecommunications, environmental matters and more. 
McKinsey \& Company, Inc., Bain \& Company, Inc., Boston Consulting Group, Inc. and a handful of other companies are the most elite. Such firms may charge their clients anywhere from $\$ 300,000$ to $\$ 1$ million in monthly fees, billing top consultants at as much as $\$ 5,000$ daily plus expenses, and associates at \$1,500 or so. Annual revenues at such firms runs in the billions of dollars, and top consultants may earn $\$ 200,000$ to $\$ 500,000$ or more yearly.

The growing globalization of business and industry in general has led inevitably to the globalization of the leading consulting companies. Major consultancies operate offices in the most important business centers in Europe and Asia-Pacific as well as in North and South America. Many operate worldwide and have multiethnic, multilingual employee bases.

In contrast to the size and fame of the leading management consulting companies, a large portion of the consulting industry is comprised of very small companies -in many cases these are one-person shops. These professionals have turned to selfemployment as consultants, focusing on their specialties.

During the consulting slump of the early 2000s, many consultancies resorted to mergers with partners; others instituted layoffs and otherwise slashed their expenses. Besides, some great global companies built their corporate internal consulting staffs in an effort to control costs and results.

$\square$ Management Consulting Boutiques have grown rapidly since 2000, as well educated, highly qualified and thoroughly experienced executives and professionals were laid-off during corporate downsizing. Today, however, consulting companies in general expect healthy growth, particularly in projects with clients based in the U.S., Asia and parts of Europe. Even the Japanese economy is bouncing back after decades of stagnation, creating significant new business opportunities for consultants.

Going forward, consulting firms will be forced to compete fiercely for their engagements, and the engagements they receive may be relatively short-term or less profitable than assignments of the past. Corporate clients will be focused on a provable return on investment for their consulting dollars spent. Specific goals will be set early in the process, and consultants will be under intense pressure to meet those goals.

Large, multifaceted consulting companies will face intense competition from smaller, niche companies (Management Consulting Boutiques). In particular, consultancies that can help implement outsourcing and off-shoring, or further their clients' desires to increase revenues in rapidly-growing foreign markets, may have the best competitive advantage over the mid-term. Corporate clients may lean toward hiring consultancies with a proven ability not only to point out a corporation's problems and strategic deficiencies, but also to implement directly solutions in distant lands. 


\section{Global Corporate Networking and Internal Consulting Groups}

The new social and economic trends shape the global landscape. Anticipating their impact can help global companies succeed by riding the current market-space competition rather than fighting against it.

Large companies must innovate to take advantage of global trends without jeopardizing the core business. According to new research, companies that shift their portfolios to align them with favourable trends are much more likely to achieve strong growth and profits.

Executives must understand the full range of subtrends behind each trend and how they interact to affect many industries and not just the obvious ones. They can succeed by combining the scale assets of global networks to create and amplify the value of their innovations.

The globalisation is changing the world economic order and the consulting industry needs to face up to the new global market place and address the following challenges: the impact of changing competitive advantage (Market-Driven Management); government focus on outsourcing services and processes; growing tension between regulation and advisory services; the responsibility for consultancies to prove the value they are offering; and finally the invasive impact of technology and digital communications on the nature of services of management consulting; that is, the increasing automation of processes will lead to the streamlining and elimination of not just low value-add transaction services, but also will change the nature of functions from a managerial emphasis to a decision support one.

'Four years ago, Deloitte \& Touche was the only one of the Big Four accounting firms that hadn't already dumped its lucrative consulting arm. And pressure for the split was high inside and outside the firm--including from the Securities \& Exchange Commission. Today, consulting is Deloitte's second-largest business in the U.S., a \$3 billion segment that accounted for more than a third of the U.S. firm's 2006 revenue, second to auditing. Worldwide, consulting is an even bigger business for Deloitte, totalling $\$ 8.9$ billion, or $45 \%$ of its $\$ 20$ billion in global revenue. But Deloitte is not unique. It hasn't taken long for the other audit firms to do the math and quickly rebuild their own consulting arms. Worldwide, KPMG last year sold \$5.3 billion worth of consulting services, a 12\% jump from the year before. PricewaterhouseCoopers took in $\$ 3.7$ billion, up 20\%, and Ernst \& Young rang up \$2.4 billion, a 2\% increase. Given what happened at Enron, WorldCom, Adelphia, Tyco, and elsewhere, it's ironic that the very dangers those meltdowns highlighted are what's driving much of the demand for Big Four non audit services today. M\&A deals that used to be done on the CEO's handshake now take months of financial due diligence. Once-permissive credit markets are finally demanding tough financial reviews of debt, which adds to the need for the accounting firms' number-crunching prowess'. (Business Week, September 2007). 
Globalisation is both the greatest threat and opportunity for management consulting industry. Large consultancy networks will continue to globalise to deliver services from competitively priced resource pools. Niche players may survive locally but middle sized players will be challenged. The consultancy offer is becoming more clearly defined within the global segmentation. The industry that has emerged from this is more focussed on adding value by helping organisations improve their performance and challenging traditional industry models.

Clients are much saver in terms of consulting services and a lot of developing shared services organization is hiring former consultants to act internally. These internal consultants are helping procurement departments set performance and pricing benchmarks, and cutting down the pool of vendors. Value is not measured by how many hours are spent in a client office, even though this is still the predominant industry billing model. Both consultancies and - more importantly their clients will need to link consultancy rewards to the value they create.

$\square$ A study hold by the U.K. Management Consultancies Association
reports that while the overall U.K. consulting industry achieved 18
percent growth in revenues between 2005 and 2006, revenue per
consultant fell 6 percent overall during that same time. Since 2003,
revenue per consultant has dropped 12 percent. The situation is similar
in the United States.

Improving global board performance in different national markets, corporations set up their own internal consulting groups, hiring internal management consultants either from within the corporation or from external management consulting firms. Many of biggest global corporations have internal groups of as many as 20 or 40 full-time consultants.

The internal consultant approach offer different reasons. First of all, global networks want a focus group that more closely works with, and monitor, consulting firm relationships. Besides, the global corporation wants to maintain certain corporate information private. Finally, they want to model a project on a global base and do not want to pay the large, global fees typically associated with external consulting firms. Often, the internal consultant must devote less time on learning a project due to familiarity with the corporation, and is able to develop a project through to implementation a step that would be too costly if an external consultant organization were used.

Internal consulting groups are often formed around a number of practice areas. The more common areas are: competitive process management, information technology, design services, organizational and training competitive development. Internal consulting groups present some potential problems. First, when the external consulting networks are highly specialized, it is increasingly difficult to recruit independent consultants who are of the same professional profile as those working for consulting firms. Second, the internal consultant may not bring the objectivity to the consulting relationship as an external organization. Finally, when balance sheet get tough, often the internal consulting group is the first to be discharged.

The move toward outsourcing and increased competition is contributing to pricing pressures in the management consulting industry. Globalization has increased 
competition and maybe even led toward a commoditization of services. As globalization persists, consulting industry will be going to start competing a lot more on price. The net effect even though these firms are successful and profitable, their margins have been hurt to a degree will reduce investments in business growth.

The movement to global supply chains for products is already being mirrored in services. The rise of firms operating transactional services across the globe is a forerunner for the movement of more complex and valuable activities such as analysis and advisory services to be provided from developing economies, such as India and China. 